\title{
UUSIN YHTEISKUNTA JA AIDON POSITIVISMIN HENKI
}

Hallittu rakennemuutos -kirjansa (Helsinki 1987) johdannossa Matti Kortteinen asettaa yhteiskuntatutkimukselle ja itselleen - tehtävän:

"Nimenomaan tässä on tutkimuksen ja tieteen tehtävä. Nyt pitäisi empiiristen, so. havaintoaineistojen valossa selvittää, mitä tällä hetkellä todella on tapahtumassa, jotta keskustelu tärkeistä yhteiskuntapoliittisista linjanvedoista ei pohjautuisi yksin filosofiseen tai futorologiseen ajatteluun." (s. 17). Kortteisen mielestä luotettavaa tutkimustietoa rakennemuutoksen suunnasta on vielä toistaiseksi vähän. Juuri Kortteisen tarkoituksena on sekä tuottaa tällaista tieteellistä tietoa että avata aiheesta yhteiskuntapoliittista keskustelua, joka vähitellen tulisi johtamaan tieteelliseen tietoon perustuvaan yhteiskuntapolitiikkaan - ja aidosti hallittuun rakennemuutokseen. Kortteisen luottamus yhteiskunnan kehitystä koskevan tieteellisen tiedon kasvuun ja sen merkitykseen yhteiskuntapoliittisessa päätöksenteossa on ihailtavaa, mutta samalla oireellista. Kun seuraavassa - pirun tavoin ryhdyn Kortteisen ohjelmaa kommentoimaan se osoittautuu myös muilta, sisällöllisemmiltä osiltaan tämän saman aidon Saint-Simonin ja Comten positivismin hengen läpitunkemaksi, joka pahimmillaan tulee esille myös koulumestarimaisen opettavaisena esitystyylinä.

Moniin Kortteisen huomautuksiin ja varauksiin, jotka koskevat työn tutkimuksen traditioita ja perinteisiä ajattelutapoja on helppo yhtyä. Varmaan on niin, että uuden tekniikan - mukaanlukien tietotekniikan - käyttöönotto ei johda kaikkialla ja välttämättä työn sisällön köyhtymiseen ja työntekijöiden ammattitaidon laskuun. Bravermanin teesinä tunnetuksi tulleeseen ajatukseen, jonka mukaan kapitalismin kehitys johtaa suoraviivaisesti työn köyhtymiseen ja jatkuvaan osittamiseen on varmasti syytä suhtautua kriittisesti. Kortteinen huomauttaa myös viisaasti, ettei uuden tekniikan käyttöönotto suinkaan johda välttämättä ja suoraviivaisesti työttömyyden kasvuun niinkuin pessimistisimmät uskovat. Työvoiman kysyntä riippuu toki myös talouden laajenemisen vauhdista. Eivätkä ne yritykset jotka uutta tekniikkaa soveltavat suinkaan ole niitä jotka työvoimaansa vä- hentävät. Tällaisia asioita on varmasti hyvä problematisoida ja pohtia eriytyneemmin kuin usein uudesta teknologiasta puhuttaessa tehdään.

Kortteinen on myös vahvoilla huomauttaessaan, että uudella tietotekniikalla on erilaisia seurauksia erilaisissa töissä. Eikä tehtaasta toimistoon siirtyminenkään varmasti käy vaivatta työvoiman kysynnän mukaan - ehkei aina tehtaasta tehtaaseenkaan.

Mutta tämän jälkeen Kortteinen vasta aloittaa varsinaisesti oman diagnoosinsa yhteiskuntamme ongelmista ja esittää viitteitä niiden ratkaisemiseksi. Kortteinen maalaa ensin vastustajiensa muotokuvan. Yhteiskunnallisen kehityksen ja järkevän yhteiskuntapolitiikan vastustajia ovat ne, jotka eivät osaa tai halua käyttää uutta tietotekniikkaa sen suomien mahdollisuuksien mukaisesti. Vastustajia ovat sekä vanhakantaiset työnantajat että työntekijät ja heitä edustavat työmarkkinajärjestöt. Työnantajat eivät osaa hyödyntää uuden tekniikan mahdollisuuksia edes silloinkaan kun se heille selvästi olisi taloudellisesti edullista, ja he toimivat siten usein sekä omaksi että työntekijöidensä vahingoksi. Lisäksi he usein estävät työntekijöiden pyrkimyksiä kehittää omaa työtään. Toisella puolella taas ammattiyhdistysliike on yhtä vanhakantainen. Se on omaksunut jarruttavan asenteen uuteen tietotekniikkaan. On siis olemassa uutta tekniikkaa, on olemassa ihmisiä, jotka sekä osaavat että olisivat halukkaita sitä käyttämään taloudellisesti tehokkaasti ja omaa työtään rikastuttaen, mutta jokin estää tämän.

Mikä tämä jokin sitten on? Mistä tämä nurinkuriselta johtuva tilanne oikein johtuu? Kortteisen selitys on kiinnostava. Syynä on kulttuurinen viive, vanha työkulttuuri ja työpaikkojen jäykät sisäiset kulttuuriset rakenteet. Toisella puolella ovat työnantajat vanhentuneine asenteineen ja oppeineen; MTM-opit, tayloristinen työorganisaatio-oppi jne. Toisella puolella taas ovat työntekijät, jotka on sosiaalistettu 60-luvulla työ- ja luokkataistelukulttuuriin. Sekä työntekijöiden että -antajien järjestöt ovat pihalla, eivätkä tajua edes omaa parastaan. Kortteinen vielä korostaa selityksensä voimaa toteamalla Durkheimin tavoin, että tämä työkulttuuri on sosiaalinen tosiasia siinä kuin monet "kovemmat- kin" faktat ja vaikuttaa siten samalla voimalla. Vanha kulttuuri vaikuttaa tradition voimalla; muuta syytä tähän nurinkuriseen tilanteeseen ei oikeastaan ole. Erityisesti tilanteesta kärsivät ylemmät toimihenkilöt, joilla ilmeisesti olisi eniten kapasiteettia uuden tietotekniikan hyväksikäyttöön, mutta periaatteessa tilanne on samanlainen jokaisen tietotekniikan kanssa tekemisiin joutuvan työntekijäryhmän kohdalla. Kortteinen tiivistää diagnoosinsa aikamme sairaudesta seuraavasti: "Teollisen kapitalismin kulttuuriset ja poliittiset perinteet hallitsevat likipitäen täydelleen sitä tapaa, jolla tietotekniikkaa maassamme käytetään. Nykyisen kehityksen suunta selittyy tällä." (s. 120)

Kortteisen analyysista itse asiassa seuraa, että tieteellisen tutkimuksen ja tieteen tehtäväksi tulee sekä paikantaa tämä muutoksen este että myös julistaa muutoksen päämäärä, uusi työkulttuuri. Juuri tässä suhteessa Kortteinen osoittautuu aidon positivismin hengen elähdyttämäksi intellektuelliksi. On luotava uusi "moraali", joka vastaa tiedon ja tekniikan kehityksen vaatimuksia ja tilaa, jonka tiedemies ja tutkija on tunnistanut. Tämän intellektuelli myös onnekseen löytää yhteiskunnasta ryhmän tai luokan, joka muutoksen tulee joka tapauksessa panemaan toimeen. Tämä ryhmä on tietotyöläiset, joiden tiedot ja taidot ovat jo uudesta yhteiskunnasta. Oikeastaan tarvitaan vain, että tämä ryhmä itse tajuaa kehityksen suunnan ja päämäärän. Ja juuri sen tutkija heille kertoo. Comtelaisittain voisi ongelman muotoilla myös niin, että tiedemiesten 'capacite positiven' tulee kohdata - ei enää 'capacité industrielle' - vaan tällä kertaa 'capacité postindustrielle'. Kun tämä tapahtuu uusi kulttuuri syntyy ja uusi yhteiskunta onkin jo tosiasia.

Kortteisen ajattelu, josta edellä olen tunnistavinani aidon 1800 -luvun puolivälin positivismin henkäyksen, ei suinkaan tässä suhteessa ole mitenkään ainutlaatuista. On itse asiassa niin, että samanlainen ajattelu- ja analyysitapa toistuu - toki monin variaatioin varsin monissa postindustriaalisen tai informaatioyhteiskunnan visioissa, joille on yhteistä se, että ne paikantavat yhteiskunnallisen muutoksen tarpeen ja mahdollisuuden uuteen tietoon ja tekniikkaan (ks. Virve Mertanen-Halisen 


\section{Tieteellinen elämä}

sosiologian pro gradu -tutkielmaa Jälkiteollisen yhteiskunnan visiot Bellillä, Tourainella ja Masudalla, Helsingin yliopisto 1987). Kortteisen erottaa monista muista informaatio- tai jälkiteollisen yhteiskunnan visionääreistä tietty varovaisuus, se, että hän rajoittaa analyysinsa lähinnä työelämän ja -organisaatioiden tulevaisuuteen. Kortteiselta puuttuu laajempien poliittisten tai valtiollisten muutosten tarkastelu - ellei sellaiseksi sitten katsota "virta vie kokoomukseen" -ennustetta. Tässä suhteessa toki tällaiset tulevaisuudenvisiot tarjoavat lukijalle valinnanvaraa; ääripäinä ovat toisaalta käsitys kaikki edustukselliset elimet ja hallintobyrokratian korvaavasta suorasta osallistuvasta demokratiasta, jonka tieto ja informaatiotekniikka tekee mahdolliseksi, ja toisaalta puhdas teknokraattinen eliittiajattelu, kyvykkäimpien järkevä hallinto. Kuitenkin eräässä mielessä Kortteisen uusi yhteiskunta on myös tässä suhteessa varsin lähellä Saint-Simonin ja Comten industriaalista yhteiskuntaa: Kortteisen jäljittämä yhteiskunnallinen vapautuspyrkimys suuntautuu kaikkia jäykkiä ja vanhoja hierarkioita vastaan mutta ei suinkaan poista yhteiskunnan hierarkisuutta. Se asettaa vanhojen tilalle uuden kykyjen hierarkian, uuden yhteiskunnallisen työnjaon ja jaon organisaation, jonka huipulla ovat ahkerat ja lahjakkaat tietotyöläiset. Onhan nykyinen jäykkä työpaikkahierarkia ainoana esteenä tietotekniikan järkevälle käytölle ja tietotyöläisten nyt vajaakäyttöisten kapasiteettien täydelle hyödyntämiselle - ja näin voisi väittää - uuden teknokratian synnylle.

\section{Jukka Gronow}

1. Monessa suhteessa Kortteisen Hallittu rakennemuutos muistuttaa Arthur J. Pentyn Post Industrialism -teosta vuodelta 1922 (jonka nimessä tuo termi ensi kerran esiintyi). Penty ennusti teollistuneen yhteiskunnan hajoavan ja muuntuvan desentralisoiduksi, käsityöpajoihin perustuvaksi jälkiteolliseksi yhteiskunnaksi.
RADIKAALIT MUUTOKSET Neuvostoliiton tiede- ja tutkimusorganisaatiossa ovat välttämättömiä. Näin ajattelevat monet, mutta miksi niin monet vaikenevat? Näin kysyy professori, NL:n tiedeakatemian molekyyligenetiikan laitoksen osastonjohtaja Maksim FrankKamenetskii Literaturnaja Gazetan maaliskuun numerossa (16.3.88). Frank-Kamenetskiin mukaan hallinnonuudistus, joka toteutettiin vain vajaat kaksi vuotta sitten on jo osoittautunut epäonnistuneeksi. Tuolloin Tiedeakatemian laitoksilla lisättiin olennaisesti niiden johtajien vaikutusvaltaa vanhojen kollegiaalisten ja edustuksellisten elinten kustannuksella. Tämän uudistuksen tarkoituksena oli tehostaa tutkimustoimintaa ja vähentää hallintobyrokratiaa. Tuloksena oli, että käytännössä johtajat (akateemikot) voivat melko pitkälle itse päättää mitä kukin tekee ja tutkii, keitä palkataan töihin ja mitä tutkimusongelmia laitokset pyrkivät ratkaisemaan. Instituuteista tuli niiden johtajien antamien tehtävien toteuttajia. Tämä on johtanut vain ylenmääräiseen varovaisuuteen aiheiden ja tehtävien valitsemisessa ja asettamisessa sekä aloitteellisuuden ja tehokkuuden lamaantumiseen. FrankKamenetskii ei kaipaa paluuta vanhaan, ei liioin tutkimuslaitosten alistamista ministeriöille tai korkeakouluille, joita molempia vaihtoehtoja on ehdotettu. Edellinen johtaisi vain tieteen byrokratisoitumiseen, jälkimmäinen piristäisi kyllä yliopistoja — jota sitäkin kipeästi kaivataan - muttei auttaisi tutkimusta.

Mistä Frank-Kamenetskii sitten hallinnonuudistusmallinsa ottaa? Tietenkin Länsi-Saksasta ja Yhdysvalloista. Hänen ehdotuksensa on, että tulisi ratkaisevasti lisätä tutkimuslaitosten perusyksikköjen, tutkimusryhmien, laboratorioiden ja osastojen itsenäisyyttä. Niiden johtajat ovat vielä aktiivisia tiedemiehiä, usein alansa huippuja. Tiedeakatemian ja ministeriön tulisi turvata niille tietty perusrahoitus ja -palkkaus. Muutoin niiden tulisi kilpailla vapaasti tutkimusrahoituksesta keskenään. Ne saisivat huolehtia sekä rahoituksestaan että henkilöstöpolitiikastaan itse. Rahoittajina toimisivat säätiöt, ministeriöt ym., joille tutkimusryhmät voisivat esittää tutki- mussuunnitelmiaan, joita kulloinkin arvioisivat riippumattomat asiantuntijat, referendit. Erityisen tärkeää olisi käyttää arvioijina ulkomaisia asiantuntijoita. Vain siten Neuvostoliiton tiede voi tulevaisuudessa pärjätä kansainvälisillä markkinoilla.

Tiedeakatemian laitokset olisivat vain tutkimusyksikköjen johtajista koostuvan tieteellisen neuvoston johtamia katto-organisaatioita, eräänlaisia kooperatiiveja (päivän sana Neuvostoliitossa!), joiden tehtävänä olisi vain tieteen ja tutkimuksen infrastruktuurista huolehtiminen. Muutoin tutkimusryhmät saisivat vapaasti kilpailla keskenään sekä rahoituksesta että parhaista tutkijoista, joiden hinta määräytyisi kansainvälisen sitaatti-indeksin mukaan! Samalla pantaisiin vauhtia tutkijakiertoon niin sukupolvittain kuin maantieteellisestikin, millä ei voisi olla kuin tervehdyttävä vaikutus neuvostotutkimukseen.

BRITTILÄISEN kulttuuritutkimuksen suunnannäyttäjä, professori Raymond Williams kuoli 26. tammikuuta 66 vuoden iässä. Williams, walesilaisen rautatieläisen poika, loi maineensa jo tuotteliaan uransa alkuvaiheessa teoksellaan Culture and Society (1958). Siinä hän luotasi teollisen sivilisaation sekä sen taiteen ja ajattelun traditiota Coleridgesta Orwelliin. Williams laski teoksellaan perustan uudelle kulttuurista ja yhteiskunnasta kirjoittamisen traditiolle sekä opinalojen välisten tutkimusprojektien ja kurssien synnylle 1960-luvulla varsinkin uusissa brittiyliopistoissa.

Williamsin asema brittiyhteiskunnassa ja tiedeyhteisössä oli kaksinainen. Yhtäältä hän saattoi olla ylpeä asumisestaan Coleridgen huoneessa ollessaan Cambridgen yliopiston Jesus Collegen jäsen, mutta toisaalta hän etsi omaa tietään ulos brittiläisen kirjallisuudentutkimuksen traditiosta. Yhtäältä hän oli koko ikänsä lähellä marxismia, toisaalta hän ei ottanut marxismissa vallitsevina olleita kulttuurin tarkastelun lähtökohtia annettuina, vaan etsi omaansa.

Williamsin tuotteliaisuus on tunnettua, mutta hänet tunnettiin säkenöivänä luennoijana, joka sai salit täyttymään myös 60-luvun lopussa, kun luennot eivät yleisesti ottaen nauttineet suurinta 